\title{
MATHEMATICAL MODELING OF NOISE LEVEL IN THE WIND PARK AREA
}

\author{
Mihai Bratu, Valeriu Danciulescu, Elena Bucur, Andrei Vasile
}

National Research and Development Institute for Industrial Ecology - ECOIND, 71-73

Drumul Podu Dambovitei Street, sector 6, zip 060652, Bucharest, Romania

*Corresponding author's email address: cmm_bratu@yahoo.com

\begin{abstract}
In the actual period the environmental protection is a major problem to humanity. In most countries of the world are set to impose measures to limit pollution. International conventions were signed harmonizing these measures. Economic development entails environmental concerns in general and in particular the noise. In this paper are analyzed in terms of noise emission three wind parks in the county of Constanta. Wind energy has been used since ancient times earning a good tradition. In particular, a broader and widespread use of wind energy has many advantages for both technical nature (safe energy source to natural ecosystems, with a possible high overall efficiency, simplicity of construction and during installation) and economic (financial investment reduced operating costs and relatively low maintenance). Turbines for producing electricity are installed in areas with air currents present almost throughout the year. Also nearby wind parks are rural villages with a potential impact in terms of noise. Measurements were performed on each turbine noise wind parks belonging and the data obtained was performed mathematical modeling and drafting papers on noise dispersion in the areas studied.
\end{abstract}

Keywords: dispersion, mathematical modeling, noise map, turbine, wind park

\section{Introduction}

The Industrial Development Policy in the coming years aimed at transforming the industrial economy into an economy based on sustainable development and performance consistent with the long term interests of the country and the environment, by integrating in the EU on economic partnership principles. It promotes today in Romania an industrial policy on the principles of competitiveness, in order to increase capacity adapatre Romanian economy to the demands of increasingly higher market, in terms of trends of economic globalization, where the goal undeclared but real is the market [1]. Development of the economy, industry, entail serious concerns about environmental pollution.

This is environmental contamination with materials that harm the health, quality of life or functioning of natural ecosystems. Although some environmental pollution is a result of natural action is mostly caused by human activity [2]. We live in a world of sounds undoubtedly essential in terms of communication and / or information transfer. Nature provides us with an abundant variety of sound sources, but the man-usually raise problems for environmental health.

Noise pollution is human or animal exposure to sound levels disturbing, distressing or harmful [3]. Noise pollution generally refers to unwanted sound produced by human activities undesirable in that it interferes with 
communication, work, rest, recreation, or sleep. Unlike other forms of pollution, such as air, water and hazardous materials, noise does not remain long in the environment (4).

The development of electrical power production systems including renewable energy sources is of outmost importance. Wind energy is one of the most efficient and promising renewable energy sources. In recent years, a significant rise in the total wind energy capacity of the European Union (EU) emerged, as a result of the request for the increase of the clean energy technologies contribution to the total energy production [5]. According to [6], at the end of 2010, worldwide capacity of wind-powered generators was 196,630 MW, out of which $37,642 \mathrm{MW}$ were added. All wind turbines installed by the end of 2010 were generating 430 TW h per annum, equal to the $2.5 \%$ of global electricity consumption.

The paper aims to assess noise from windfarms area by creating noise maps. It will determine the dispersion of noise from that source wind turbine at specific receptors and residents near these turbines [6].

\section{Experimental}

They performed measurements of noise levels at three wind farms in the county of Constanta. During noise measurements it was taken into account wind speed and direction and barometric pressure environmental conditions, the temperature of air and atmospheric conditions and humidity. To make noise map took into account both the level of noise produced by wind turbine (data from manufacturer) the wind speed and direction.

In Figure 1 is shown indicating wind direction wind rose for all three wind farms studied.

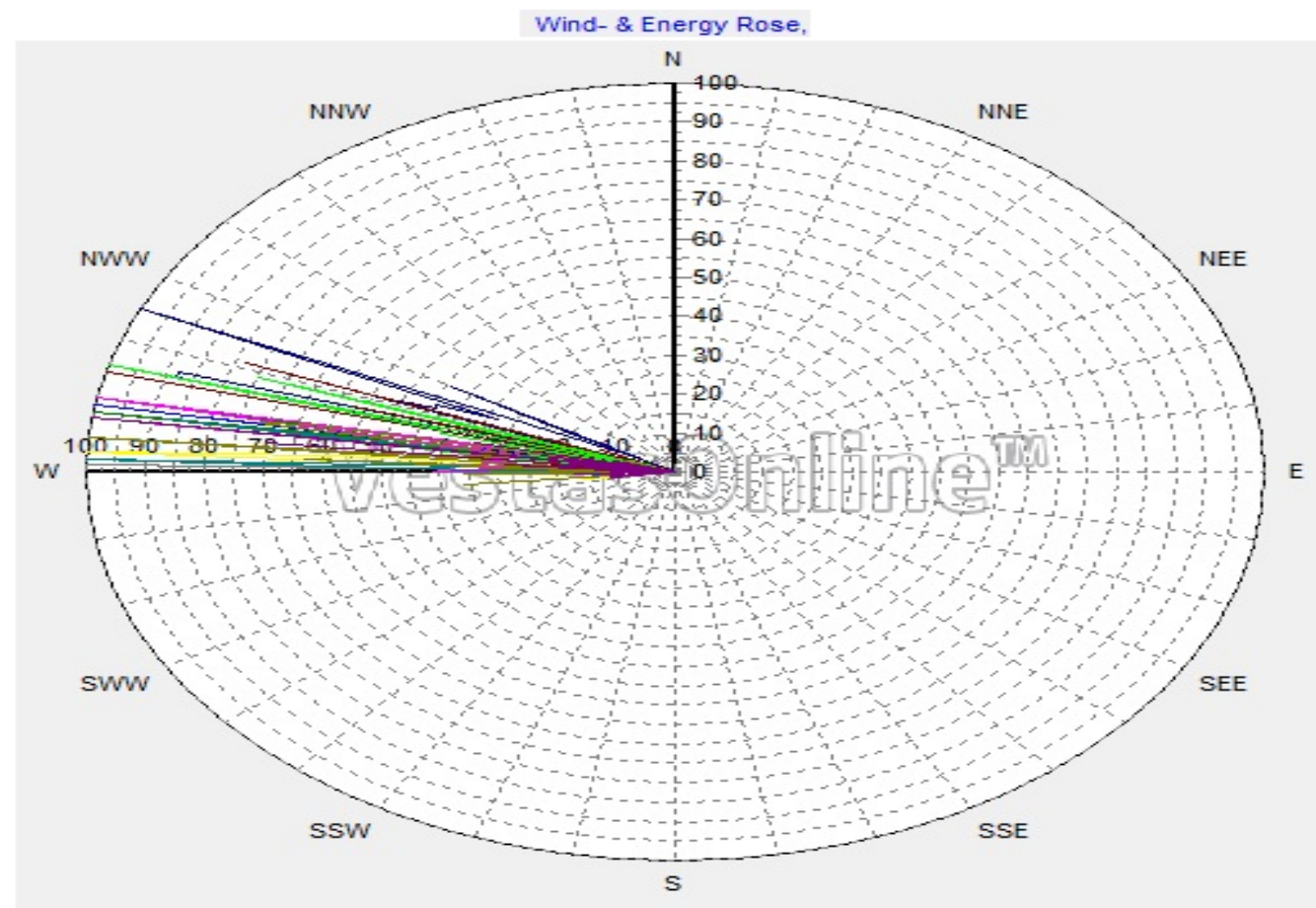

Figure 1. Wind Rose 
Also, under current legislation, they were chosen by two points for each wind farm measuring points arranged closest to the wind turbine and the nearest dwelling. For wind park Cermavoda were selected 4 measuring points because it has a large area on the layout of wind turbines. Table 1,2,3 noise present the values determined at each measurement point.

\section{Table 1}

The results of the measurements for noise

To Wind Pestera Park

\begin{tabular}{|c|c|}
\hline \multirow{2}{*}{$\begin{array}{l}\text { The point where } \\
\text { measurements were }\end{array}$} & $\begin{array}{c}\text { Measurement } \\
\text { results }\end{array}$ \\
\hline & $\mathrm{L}_{\mathrm{eq}}, \mathrm{dB}(\mathrm{A})$ \\
\hline $\begin{array}{c}\text { P1 - Coordinates point } \\
\mathrm{X}(\mathrm{m}) \text { 742773,086; } \mathrm{Y}(\mathrm{m}) \quad 307635,044\end{array}$ & 39,3 \\
\hline $\begin{array}{c}\text { P2 - Coordinates point } \\
\mathrm{X}(\mathrm{m}) 744015,384 ; \mathrm{Y}(\mathrm{m}) 307508,822 \\
\end{array}$ & 37,8 \\
\hline
\end{tabular}

Table 2

The results of the measurements for noise

To Wind Cernavoda Park

\begin{tabular}{|c|c|}
\hline $\begin{array}{c}\text { The point where } \\
\text { measurements were }\end{array}$ & Measurement results \\
\cline { 2 - 3 } $\begin{array}{c}\text { P1 - Coordinates point } \\
\mathrm{X}(\mathrm{m}) 746445,9 \mathrm{~N} ; \mathrm{Y}(\mathrm{m}) 314600,3 \mathrm{E}\end{array}$ & 37,7 \\
\hline $\begin{array}{c}\mathrm{P} 2-\text { Coordinates point } \\
\mathrm{X}(\mathrm{m}) 746939,91 \mathrm{~N} ; \mathrm{Y}(\mathrm{m}) 314010,76 \mathrm{E}\end{array}$ & 38,4 \\
\hline $\begin{array}{c}\mathrm{P} 3-\text { Coordinates point } \\
X(\mathrm{~m}) 743350,73 \mathrm{~N} ; \mathrm{Y}(\mathrm{m}) 314800,18 \mathrm{E}\end{array}$ & 34,7 \\
\hline $\begin{array}{c}\mathrm{P} 4-\text { Coordinates point } \\
X(\mathrm{~m}) 754212,14 \mathrm{~N} ; \mathrm{Y}(\mathrm{m}) \text { 314658,33E }\end{array}$ & 34,4 \\
\hline
\end{tabular}

Table 3

The results of the measurements for noise

To Wind Cobadin Park

\begin{tabular}{|c|c|}
\hline $\begin{array}{c}\text { The point where } \\
\text { measurements were }\end{array}$ & $\begin{array}{c}\text { Measurement } \\
\text { results }\end{array}$ \\
\cline { 2 - 2 } & Leq, $\mathrm{dB}(\mathrm{A})$ \\
\hline $\begin{array}{c}\mathrm{P} 1-\text { comuna Cobadin (coordonate } \\
\left.\text { punct } 44^{\circ} 04^{`} 17.36 \mathrm{~N} ; 28^{\circ} 13^{\circ} 43.78 \mathrm{E}\right)\end{array}$ & 29,6 \\
\hline $\begin{array}{c}\mathrm{P} 2-\text { comuna Ciocarlia (coordonate } \\
\left.\text { punct } 44^{\circ} 06^{`} 37.51 \mathrm{~N} ; 28^{\circ} 16^{\circ} 45.83 \mathrm{E}\right)\end{array}$ & 31,1 \\
\hline
\end{tabular}


In Figures 1,2 and 3 show the three wind farms studied in this paper

Figure 1. Locations of measuring noise (Irvinezu Mic - P1 - X 742773,086; E 307635,044; P2 - X 744015,384;Y 307508,822)

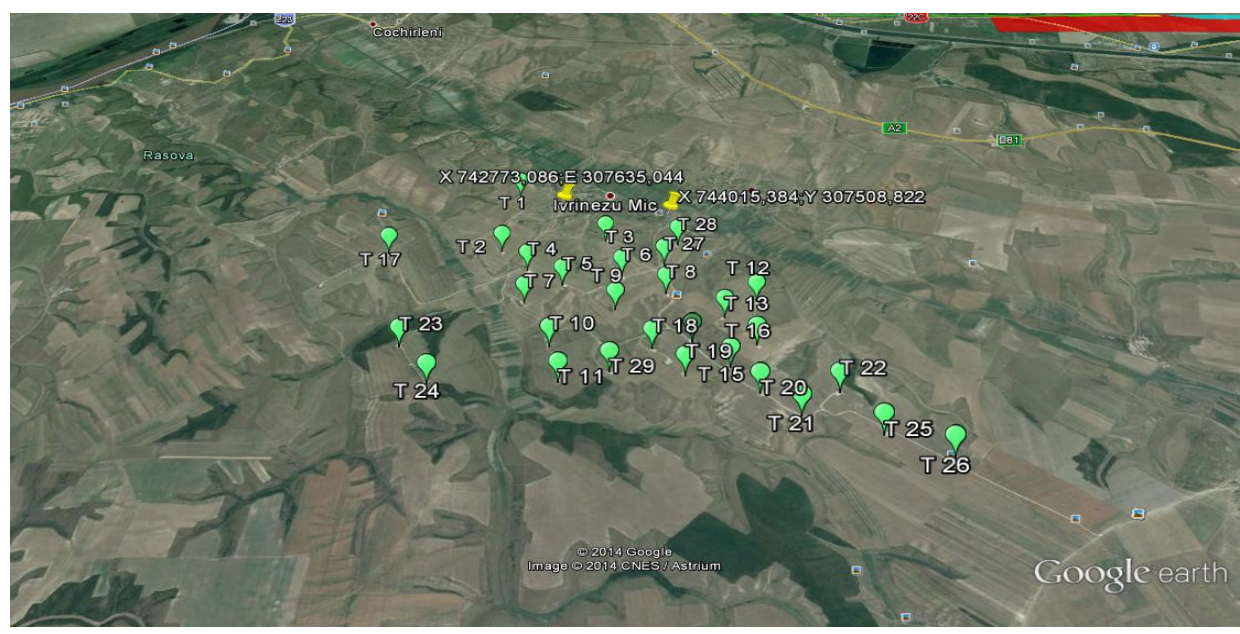

Figure 2. Locations of measuring noise (Saligny city $-\mathrm{P} 1-\mathrm{X}$ 746445,9N;Y314600,3E; P2 - X 746939,91N;Y 314010,76E); (Mircea Voda city - P1 X 743350,73N;Y314800,18E; P2 - X 754212,14N;Y 314658,33E);

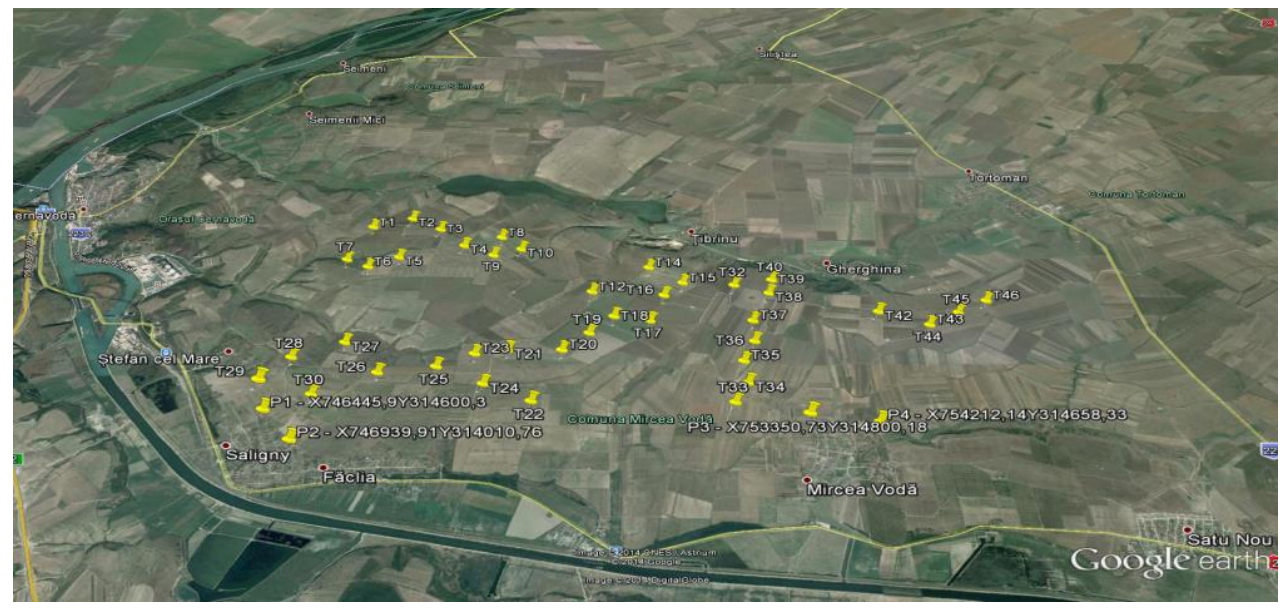

Figure 3. Locations of measuring noise: Cobadin city (coordonate punct $44^{\circ} 04^{`} 17.36 \mathrm{~N} ; 28^{\circ} 13^{`} 43.78 \mathrm{E}$ ); Ciocarlia city (coordonate punct $44^{\circ} 06^{`} 37.51 \mathrm{~N}$; $\left.28^{\circ} 16^{\prime} 45.83 \mathrm{E}\right)$

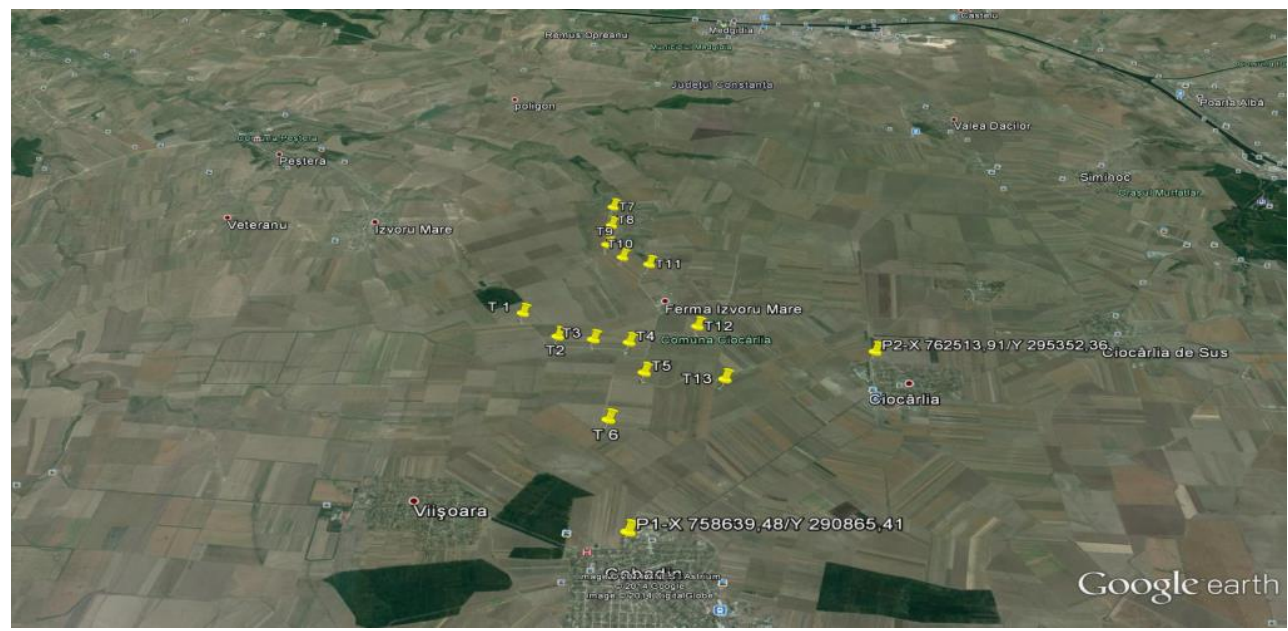




\section{Results and Discussion}

Based on data obtained from the manufacturer on each turbine noise emission but the data obtained by direct measurement of sound pressure level were conducted noise maps for each wind farm. Thus in Figure 1 shows the map of the distribution of sound pressure level noise for wind farm Pestera presentation both in plan a) and in Google Earth b).

Figure 1

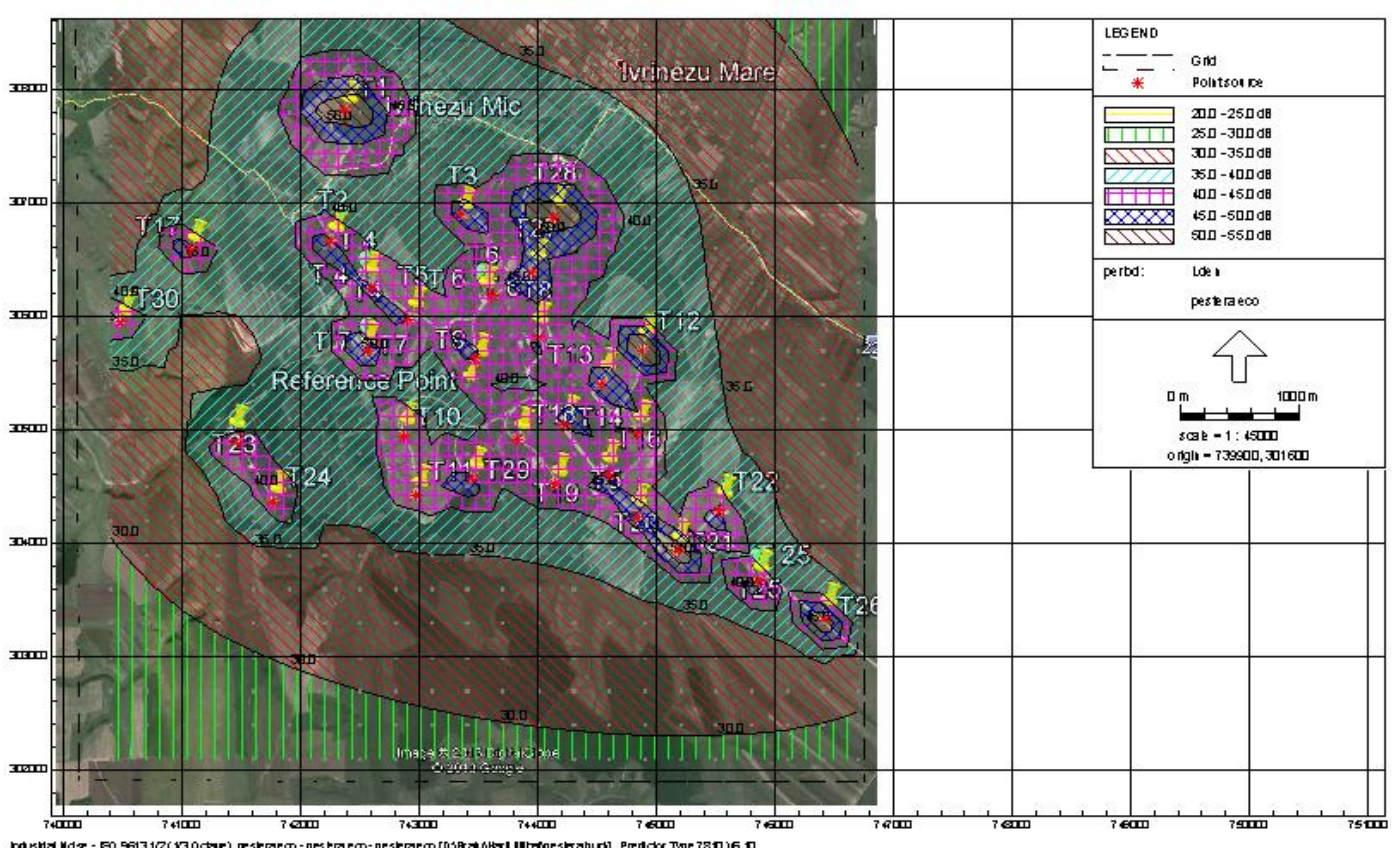

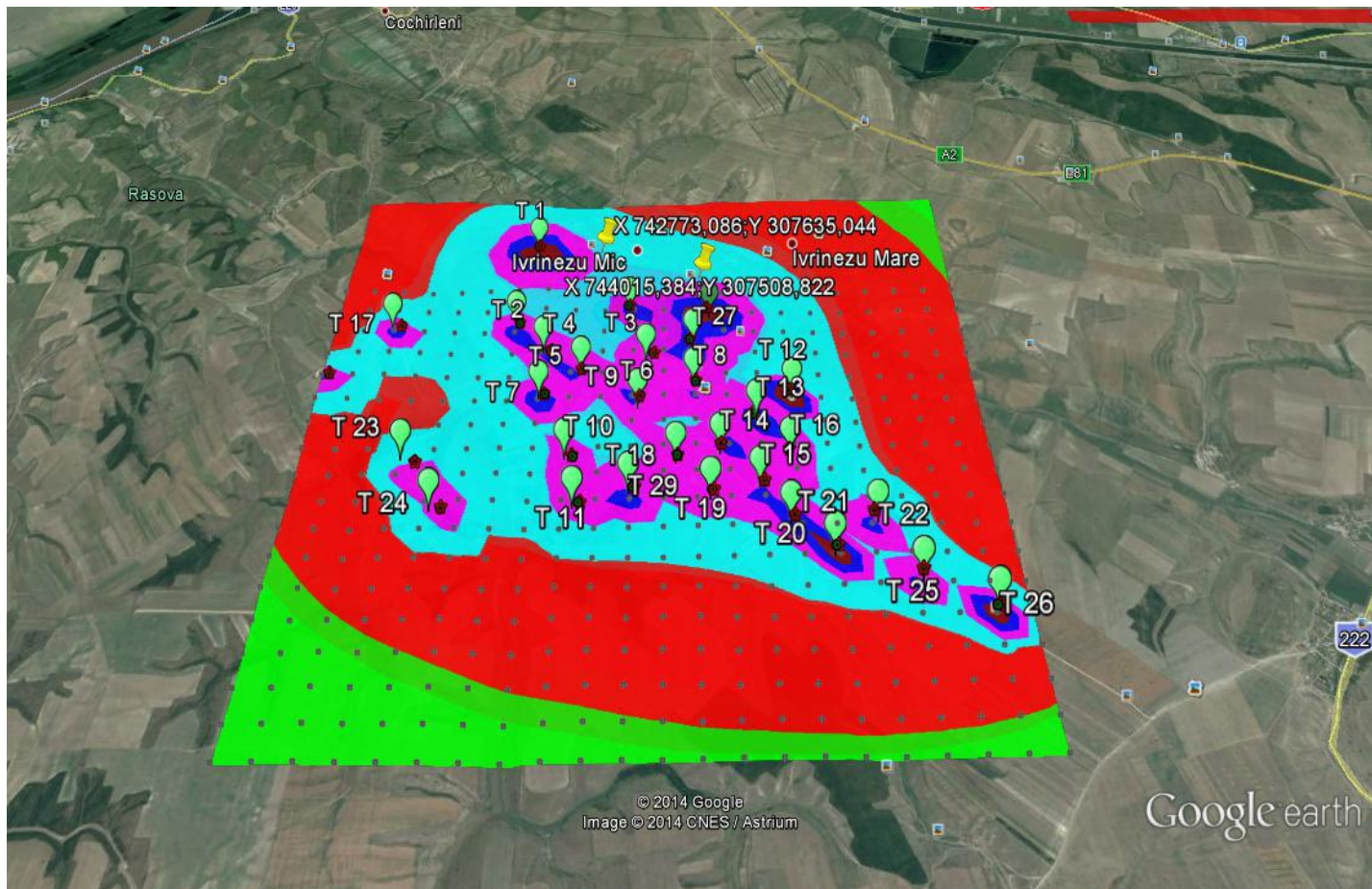

Note the turbines in obtaining noise values in the range 50-55 dB. Also in the points studied and monitored in terms of noise they were determined values for noise between 35-40 $\mathrm{dB}$. Under the legislation in force is necessary to achieve noise maps, legislation that includes Directive 2002/49/EC, Government decision 312/2015, also valorile limita pentru nivelul de zgomot masurat la limita locuintei este aratat in STAS 10009-88 [7-9]. 
In Figure 2 shows the dispersion of noise for Cernavoda wind turbine park representation both in plan a) and in Google Earth b).

\section{Figure 2}
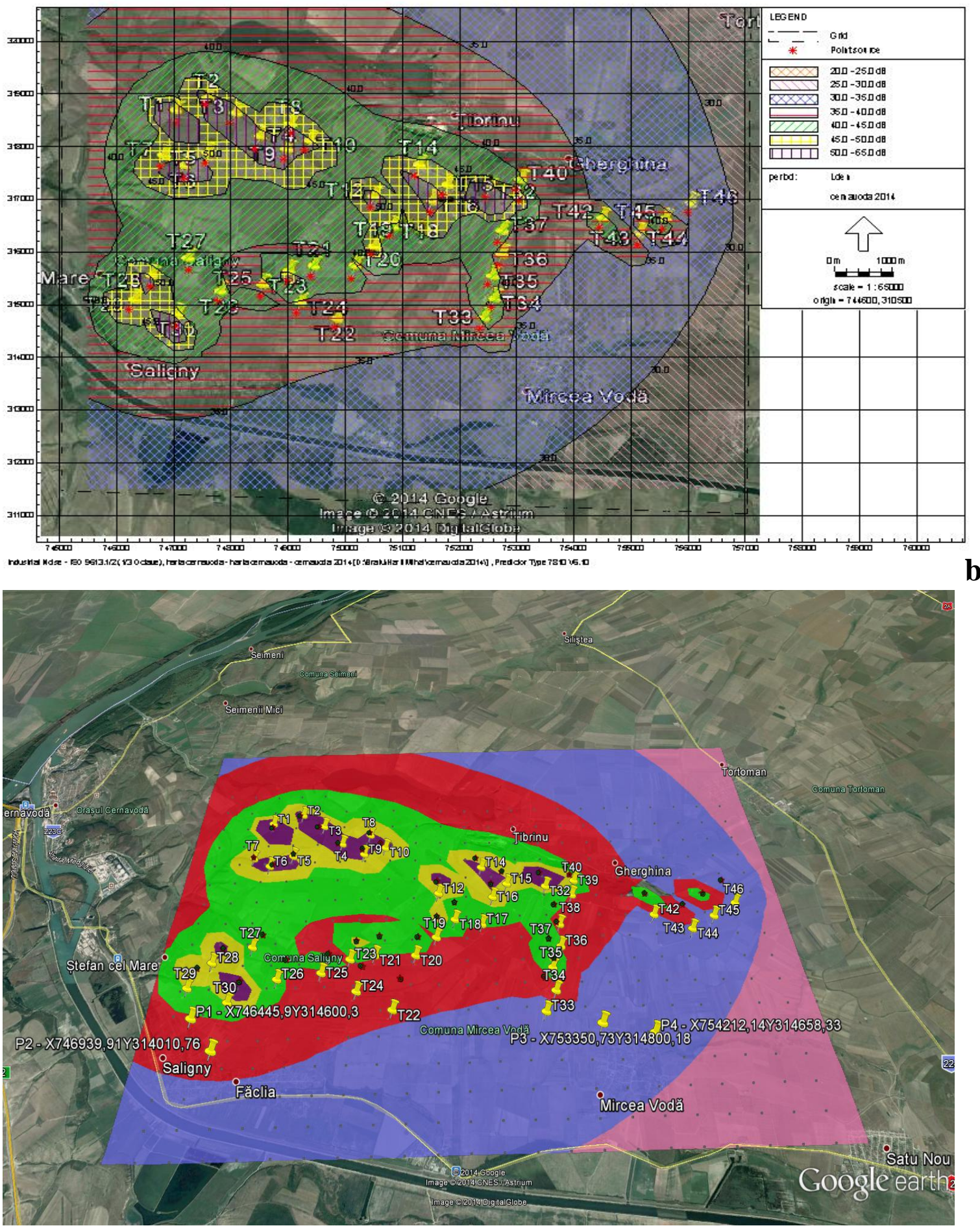

b)

Note the recording of values between $50-65 \mathrm{~dB}$ in the wind turbines. For points that were made measurements of noise limit values house were registered between 30-35 dB. 
In Figure 3 is presented for wind farm noise map Cobadin plan a) and in Google Earth b).

\section{Figure 3}
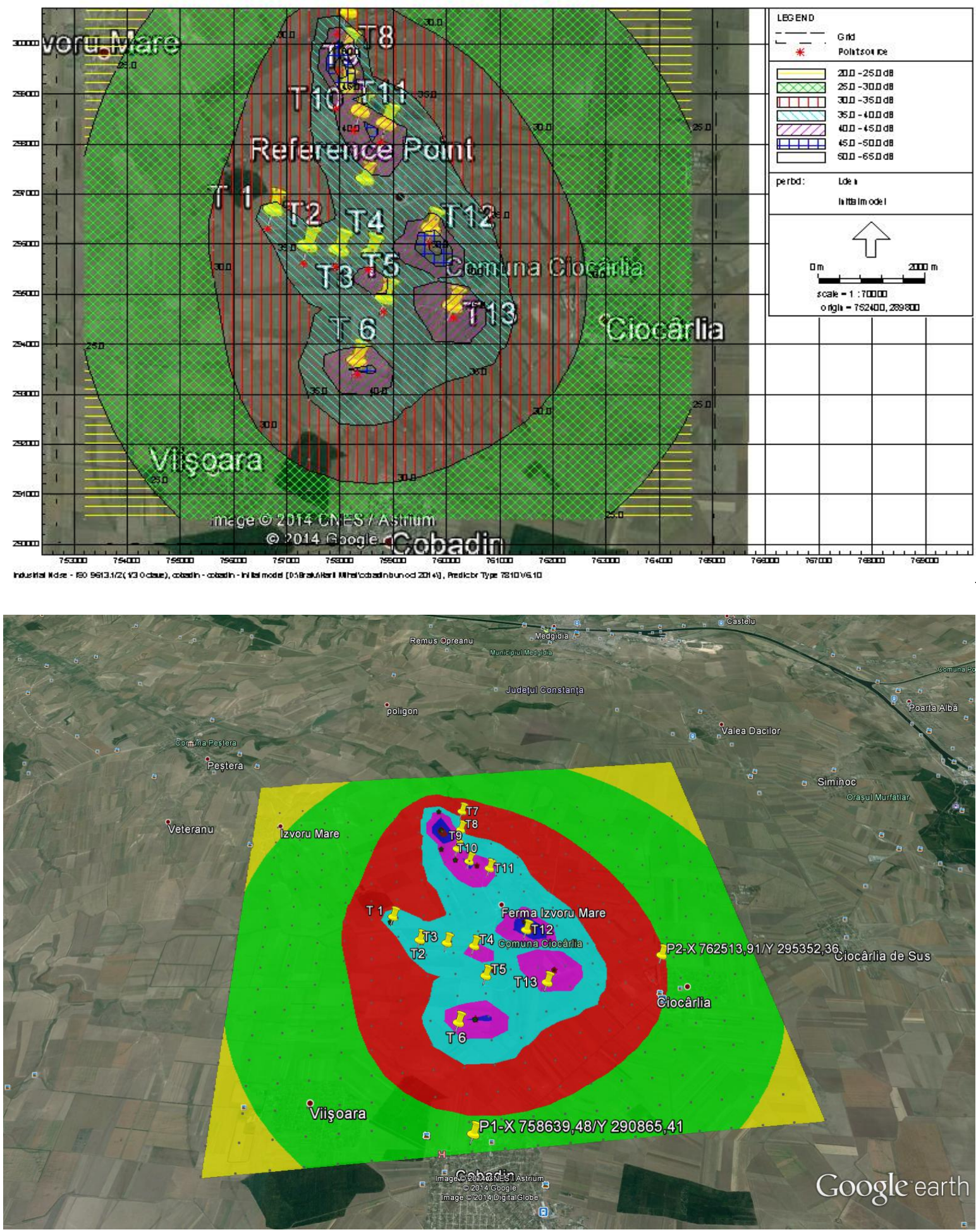

Observe the wind farm is for acetate values near wind turbines noise of $45-50 \mathrm{~dB}$. 


\section{Conclusions}

$>$ It was determined the noise levels of wind turbines for three wind farms, Pestera, Cernavoda and Cobadin.

$>$ The noise level caused accordance to legislation on noise near population is below the limit set in legislation.

$>$ S-a realizat harta de zgomot care determina dispersia nivelului presiunii acustice

$>$ Maps can be made useful to competent authorities and environmental agencies.

\section{References}

[1] E. R. Laslu, G. M. Laslu, Economic aspects of environmental protection, Publisher VOX,2003, p. 73.

[2] Paulo Henrique T. Zannin and David Q. De Sant'Ana, Noise mapping at different stages of a freeway redevelopment project - A case study in Brazil, (72), (2011), Pages 479-486.

[3] World Health Organization. Noise and Health 36; (2000), W. Passchier-Vermeer and W. F. Passchier, Noise Exposure and Public Health, p. 123-131.

[4] J.M.Samet and Y.S.Chung, Air quality, atmosphere and health, Springer Netherlands,(1998), p 5.

[5] Christos C. Eleni I. Andreas K. Anestis I. K., Comparative study of the power production and noise emissions impact from two wind farms, Energy Conversion and Management 60 (2012) 233-242.

[6] World Wind Energy Association. World wind energy report 2010. Technical report; 2011.

[7] ${ }^{* * *}$ Directive 2002/49/EC of the European Parliament and of the Council relating to the assessment and management of environmental noise, Jun. 2002.

[8] ${ }^{* * *}$ Government decision 312/2015, Assessment and management of environmental noise.

[9] ${ }^{* * *}$ STAS 10009-88, Urban Acoustics - permissible noise limits - in urban areas differentiated and functional facilities, the technical categories of streets, determined according to specific technical regulations in force concerning systematization and environment. 